\title{
Hubungan Semangat Kerja Dengan Efektivitas Pelaksanaan Tugas Pegawai Sekretariat DPRD Kabupaten Buton Utara
}

\author{
${ }^{1}$ Heri Sidin, ${ }^{2}$ Muh Askal Basir \\ ${ }^{1}$ Mahasiswa FISIP UM. Buton \\ ${ }^{2}$ Dosen FISIP UM. Buton
}

\begin{abstract}
Abstrak; Semangat kerja mempunyai hubungan erat dengan masalah efektifitas pelaksanaan tugas karena merupakan indikator dalam menentukan bagaimana usaha untuk mencapai tingkat produktivitas yang tinggi dalam suatu organisasi. Tujuan Penelitian adalah Untuk Mengetahui Bagaimanan Hubungan Semangat Kerja dengan Efektivitas Pelaksanaan Tugas pegawai di Kantor Sekretariat DPRD Kabupaten Buton Utara. Jenis penelitian ini merupakan Jenis penelitian kuantitatif dengan strategi pendekatatan Cross sectional Study, yaitu suatu penelitian untuk mempelajari dinamika korelasi antara faktor-faktor resiko dengan efek, dengan cara pendekatan observasi atau pengumpulan data sekaligus pada suatu saat dengan melihat adanya hubungan antara variabel dependen dan independen. Hasil analisis statistik menunjukan nilai sign. $0.02<0.05$ berarti disimpulkan ada hubungan antara Semangat Kerja dengan Efektifitas Pelaksanaan Tugas pegawai, sedangkan besar konstribusi semangat kerja sebesar 62,16\% terhadap Efektifitas Pelaksanaan Tugas pegawai pada Kantor Sekretariat DPRD Kabupaten Buton Utara
\end{abstract}

Kata Kunci : Semangat Kerja, Pegawai, DPRD

Abstract; The spirit of work has a close relationship with the problem of the effectiveness of the implementation of the task because it is an indicator in determining how to achieve high levels of productivity in an organization. The Research Objective Is To Know How The Work Spirit Relationship With The Implementation Effectiveness Of The Staff At The DPRD Regency North Sumatra Secretariat Office. This type of research is a type of quantitative research with a cross sectional study approach, which is a study to study the dynamics of correlation between risk factors and effects, by observing or collecting data at a time by looking at the relationship between dependent and independent variables. The results of statistical analysis show the value of sign. 0.02 $<0.05$ means that it is concluded that there is a relationship between Work Spirit and Employee Task Effectiveness, while the amount of work spirit contribution is $62.16 \%$ on the Effectiveness of Employee Tasks at the North Sumatra Regency DPRD Secretariat Office

Keywords: Work Spirit, Servant, DPRD 


\section{Pendahuluan}

Sebagaimana diketahui bahwa pada dasarnya setiap manusia hidup selalu terkait dalam organisasi bila pada zaman reformasi sekarang ini keterlibatan seseorang dalam berbagai organisasi tampaknya tidak mungkin lagi dihindari. Organisasi merupakan wadah bagi pengembangan berbagai kegiatan yang diselenggarakan oleh anggota dan untuk memenuhi kebutuhan anggotanya dalam berbagai organisasi itu sendiri. Salah satu ciri manusia modern adalah keanggotaanya dalam berbagai organisasi seperti organisasi sosial, keagamaan atau kepercayaan, keolahragaan, pemerintah dan lain sebagainya, secara keseluruhan organisasi dapat di kelompokan dalam dua bentuk organisasi yang bersifat formal dan in formal, ini semua adalah untuk memenuhi tuntutan kebutuhan yang selalu meningat. Yang semuanya dimaksudkan untuk mencapai tujuan pribadinya baik dalam arti peningkatan taraf hidupnya di bidang materil maupun manusia tersebut dibidang mental dan spiritual.

Semua bentuk organisasi memerlukan anggota atau pegawai yang diharapkan dapat melakukan atau mengerjakan tugas dan kewajiban dengan penuh tanggung jawab, sehingga dapat menghasilkan hasil yang di harapkan. Agar dapat hasil yang optimal dan semua pekerjaan diperlukan pendidikan baik sebagai dasar dari sumber daya manusia itu sendiri dan juga sebagai penunjang dalam pengerjaan perkerjaan yang diberikan.

\begin{tabular}{lrr}
\multicolumn{1}{c}{ DPRD } & adalah salah & $\begin{array}{r}\text { satu } \\
\text { dalam }\end{array}$ \\
komponen & penting & sistem \\
penyelenggaraan & suatu & pekerjaan \\
pemerintahan yang baik & pekn \\
DPRD pun ditunjang oleh Sekretariat
\end{tabular}

DPRD dimana para pegawai yang berkerja dalam Sekretariat DPRD memilih tugas penting dalam kinerja DPRD sedangkan Sekretariat DPRD adalah hal yang penting dimana menyelenggarakan Administrasi kesekretariatan DPRD, menyelenggarakan rapat, menyelenggarakan adminitrasi keuangan, menyediakan dan mengoordinasikan tenaga kerja ahli didukung oleh DPRD.

Pegawai sekretariat DPRD memiliki banyak tugas dan fungsi dimana mereka yang membantu kerja para anggota DPRD dengan menyediakan staf ahli, merancang dan merencanakan keuangan dan kebijakan serta mengatur keuangan daerah dimana semua yang dikerjakan haruslah tepat sasaran dan tepat waktu penyelesaiannya. Setelah diketahui bagaimana pentingnya kinerja pegawai di sekretariat DPRD tetap saja ada pegawai yang terlambat baik dalam mengerjakan tugas yang diberikan maupun dalam hal mentaati jam kantor sehingga lewat dari target waktu yang telah ditentukan sehingga pekerjaan tersebut tidak lagi efektif dan efisien.

Agar pelaksanaan pembangunan nasional tersebut dapat berjalan dengan baik, maka salah satu caranya adalah pemerintah harus memberikan dorongan dan semangat kerja kepada para pegawai agar mampu melaksanakan tugasnya dengan efektif dan efisien serta penuh tanggung jawab.

Pada sebuah organisasi pemerintahan, kesuksesan atau kegagalan dalam pelaksanaan tugas dan penyelenggaraan pemerintahan, dipengaruhi oleh semangat kerja dari para pegawai, melalui semangat kerja yang baik 
dan didukung oleh kapasitas organisasi pemerintahan yang memadai, maka penyelenggaraan tata pemerintahan yang baik (Good Governance) akan terwujud.

Semangat kerja yang baik yang dimiliki oleh pegawai dapat mencipkakan suatu efektifitas pelaksanaan tugas yang baik pula. Efefktifitas pelaksanaan tugas adalah suatu tingkatan keberhasilan yang di capai seseorang dengan melakukan aktifitas-afektifitas yang di berikan kepadanya dengan mendasari pengetahuan yang dimilikinya,kecakapan serta kesungguhan. Efektifitas kerja yang baik hanya datang dari pegawai yang merasa memiliki tanggung jawab terhadap pekerjaan keberhasilan suatu organisasi dalam meningkatkan efektifitas pelaksanaan tugas pegawai adalah cara kerja pegawai itu sendiri dan dukungan juga oleh orang-orang yang berpengaruh penting dalam organisasi tersebut yakni seorang pimpinan. Agar pelaksanaan efektifitas berjalan dengan baik maka perlu semangat kerja yang baik dari para pegawai. Hal ini dimaksudkan agar tidak terjadi penyimpangan, kesalahan dan penyelewengan

Salah satu alasan yang menjadikan hal tersebut sebagai pengamatan dalam melakukan penelitian awal adalah organisasi Pemerintah Sekertariat DPRD Kabupaten Buton Utara yang diketahui bahwa efektifitas pelaksanaa tugas pegawainya masih belum memuaskan. Hal ini terlihat dari gejala-gejala sebagai berikut:
a. Kedisplinan Pegawai yang masih kurang baik.
b. Standar waktu yang digunakan dalam penyelesaian perkerjaan masih kurang tepat
c. Hasil yang dicapai kurang memuaskan

Masih rendahnya pelaksanaan tugas pegawai yang ditunjukkan oleh gejala di atas disebabkan oleh beberapa faktor antara lain salah satunya adalah Semangat kerja yang masih rendah.

Aparatur pemerintah sebagai pelaksana kegiatan memerlukan semangat kerja yang baik sebagai bekal dasar sebagai penunjang pekerjaan yang dikerjakan agar mendapatkan hasil yang memuaskan. Semangat kerja mempunyai hubungan erat dengan masalah efektifitas pelaksanaan tugas karena merupakan indikator dalam menentukan bagaimana usaha untuk mencapai tingkat produktivitas yang tinggi dalam suatu organisasi. Tujuan Penelitian adalah Untuk Mengetahui Bagaimanan Hubungan Semangat Kerja dengan Efektivitas Pelaksanaan Tugas pegawai di Kantor Sekretariat DPRD Kabupaten Buton Utara

\section{Metode Penelitian}

Jenis penelitian ini merupakan Jenis penelitian kuantitatif dengan strategi pendekatatan Cross sectional Study, Menurut sugiono (2005) pendekatatan Cross sectional Study yaitu suatu penelitian untuk mempelajari dinamika korelasi antara faktor-faktor resiko dengan efek, dengan cara pendekatan observasi atau pengumpulan data sekaligus pada suatu saat dengan melihat adanya hubungan antara variabel dependen dan independen.

Menurut sugiono (2005) Analisis yang digunakan dalam penelitian ini adalah:

a. Analisis univariat

Analisis univariat yaitu analisis yang digunakan untuk menggambarkan atau mendiskripsikan dari masing-masing variabel, baik variabel bebas dan variabel terikat dan karakteristik responden 
a. Analisis bivariat

Dilakukan untuk menguji hubungan variabel bebas dan variabel terikat dengan uji statistik chi square $\left(\chi^{2}\right)$ untuk mengetahi hubungan yang signifikan antara masing-masing variabel bebas dengan variabel terikat. Uji chi square dilakukan dengan mengunakan bantuan perangkat lunak berbentuk komputer dengan tingkat signifikan $\mathrm{p}>0,05$ (taraf kepercayaan 95\%). Dasar pengambilan keputusan dengan tingkat kepercayaan 95\% :

1) Jika nilai sig $p>0,05$ maka hipotesis penelitian ditolak.

2) Jika nilai sig $p \leq 0,05$ maka hipotesis penelitian diterima (Agung,1993)

\section{Hasil Penelitian Pembahasan}

\section{Analisis Univariat}

\section{a. Semangat Kerja Pegawai}

Hasil penelitian mengenai semangat kerja pegawai antara lain :.

1) Kehadiran

Tabel 1 Distrubusi Frekuensi Semangat Kerja Pegawai berdasarkan kehadiran

\begin{tabular}{|c|c|r|}
\hline \multirow{2}{*}{ Kehadiran } & \multicolumn{2}{|c|}{ Responden } \\
\cline { 2 - 3 } & $\mathrm{N}$ & $(\%)$ \\
\hline Tidak Baik & 11 & 29,7 \\
Baik & 26 & 70,3 \\
\hline Jumlah & 37 & 100 \\
\hline
\end{tabular}

Sumber : Data Primer 2019

Berdasarkan tabel tersebut menunjukan jawaban responden atas pertanyaan yang menyangkut kehadiran yang tidak baik sebanyak 11 orang $(29,7 \%)$ kehadiran yang baik sebanyak 26 orang $(20,3 \%)$
2) Ketaatan terhadap aturan

Tabel 2. Distrubusi Frekuensi Semangat Kerja Pegawai berdasarkan Ketaatan terhadap aturan.

\begin{tabular}{|l|c|c|}
\hline \multirow{2}{*}{$\begin{array}{l}\text { Ketaatan } \\
\text { terhadap } \\
\text { aturan }\end{array}$} & \multicolumn{2}{|c|}{ Responden } \\
\cline { 2 - 3 } & $\mathrm{N}$ & $(\%)$ \\
\hline Tidak Baik & 27 & 27, \\
Baik & & 72, \\
& & 97 \\
\hline Jumlah & 37 & 100 \\
\hline
\end{tabular}

Sumber : Data Primer 2019

Berdasrakan tabel tersebut menunjukan jawaban responden atas pertanyaan yang menyangkut Ketaatan terhadap aturan yang tidak baik sebanyak 10 orang $(27,03 \%)$. Ketaatan terhadap aturan yang baik sebanyak 27 orang $(72,79 \%)$

3) Ketekunan

Tabel 3. Distrubusi Frekuensi Semangat Kerja Pegawai berdasarkan Ketekunan.

\begin{tabular}{|l|c|c|}
\hline \multirow{2}{*}{ Ketekunan } & \multicolumn{2}{|c|}{ Responden } \\
\cline { 2 - 3 } & $\mathrm{N}$ & $(\%)$ \\
\hline Tidak & 8 & 21.62 \\
Baik & 29 & 78.38 \\
Baik & & \\
\hline Jumlah & 37 & 100 \\
\hline
\end{tabular}

Sumber : Data Primer 2019

Berdasarkan tabel tersebut menunjukan jawaban responden atas pertanyaan yang menyangkut Ketekunan yang tidak baik sebanyak 8 orang (21.62\%). Ketekunan yang baik sebanyak 29 orang (78.38\%)

4) Kesenangan dalam pekerjaan

Tabel 4. Distrubusi Frekuensi Semangat Kerja Pegawai berdasarkan Kesenangan dalam pekerjaan. 


\begin{tabular}{|l|c|c|}
\hline Kesenangan & \multicolumn{2}{|c|}{ Responden } \\
\cline { 2 - 3 } dalam & $\mathrm{N}$ & $(\%)$ \\
pekerjaan & 12 & 32, \\
& 25 & 43 \\
Tidak Baik & & 67 \\
Baik & & 57 \\
\hline Jumlah & 37 & 100 \\
\hline
\end{tabular}

Sumber : Data Primer 2019

Berdasarkan tabel tersebut menunjukan jawaban responden atas pertanyaan yang menyangkut Kesenangan dalam pekerjaan pada yang tidak baik sebanyak 12 orang $(32,43 \%)$. Kesenangan dalam pekerjaan yang baik sebanyak 25 orang $(67,57 \%)$

5) Kesenangan dalam pekerjaan

Tabel 5. Distrubusi Frekuensi Semangat Kerja Pegawai berdasarkan Kesenangan dalam pekerjaan.

\begin{tabular}{|l|c|c|}
\hline Kesenangan & \multicolumn{2}{|c|}{ Responden } \\
\cline { 2 - 3 } dalam & $\mathrm{N}$ & $(\%)$ \\
pekerjaan & 12 & 32, \\
& 25 & 43 \\
Tidak Baik & & 67 \\
Baik & & 57 \\
\hline \multicolumn{1}{|c|}{ Jumlah } & 37 & 100 \\
\hline
\end{tabular}

Sumber : Data Primer 2019

Berdasrakan tabel tersebut menunjukan jawaban responden atas pertanyaan yang menyangkut Kesenangan dalam pekerjaan pada yang tidak baik sebanyak 12 orang (32,43\%). Kesenangan dalam pekerjaan yang baik sebanyak 25 orang $(67,57 \%)$

6) Hubungan antar pegawai

Tabel 6. Distrubusi Frekuensi Semangat Kerja Pegawai berdasarkan hubungan antar pegawai.

\begin{tabular}{|l|c|c|}
\hline hubungan & \multicolumn{2}{|c|}{ Responden } \\
\cline { 2 - 3 } $\begin{array}{l}\text { antar } \\
\text { pegawai }\end{array}$ & $\mathrm{N}$ & $(\%)$ \\
\hline Tidak Baik & 11 & 29,73 \\
Baik & 26 & 70,27 \\
\hline \multicolumn{1}{|c|}{ Jumlah } & 37 & 100 \\
\hline
\end{tabular}

Sumber : Data Primer 2019

Berdasarkan tabel tersebut menunjukan jawaban responden atas pertanyaan yang menyangkut Kesenangan dalam pekerjaan pada standar kerja pada standar kerja yang tidak baik sebanyak 11 orang $(29,73 \%)$. Kesenangan dalam pekerjaan yang baik sebanyak 26 orang $(70,72 \%)$

7) Kesetiaan pada organisasi

Tabel 7. Distrubusi Frekuensi Semangat Kerja Pegawai berdasarkan kesetiaan pada organisasi.

\begin{tabular}{|c|c|c|}
\hline \multirow{2}{*}{$\begin{array}{l}\text { Kesetiaan pada } \\
\text { organisasi }\end{array}$} & \multicolumn{2}{|c|}{ Responden } \\
\hline & $\mathrm{N}$ & (\%) \\
\hline Tidak Baik & 15 & 40,54 \\
\hline Baik & 22 & 59,46 \\
\hline Jumlah & 37 & 100 \\
\hline
\end{tabular}
menunjukan jawaban responden atas pertanyaan yang menyangkut kesetiaan pada organisasi pada standar kerja pada standar kerja yang tidak baik sebanyak 15 orang $(40,45 \%)$. kesetiaan pada organisasi yang baik sebanyak 22 orang $(59,46 \%)$ 


\section{b. Efektifitas Pelaksanaan Tugas}

1) Kesesuaian antara inpu,output dengan hasil pekerjaan

Hasil penelitian mengenai Efektifitas Pelaksanaan Tugas berdasarkan Kesesuaian antara inpu,output dengan hasil pekerjaan ditampilkan pada Tabel berikut.

Tabel 8 Distrubusi Frekuensi Efektifitas Pelaksanaan Tugas berdasarkan Relevansi

\begin{tabular}{|c|c|c|}
\hline Kesesuaian antara & \multicolumn{2}{|c|}{ Responden } \\
\cline { 2 - 3 } $\begin{array}{c}\text { inpu,output } \\
\text { dengan hasil } \\
\text { pekerjaan }\end{array}$ & $\mathrm{N}$ & $(\%)$ \\
\hline Tidak Efektif & 13 & 35,1 \\
Baik Efektif & 24 & 64,9 \\
\hline Jumlah & 37 & 100 \\
\hline
\end{tabular}

Sumber : Data Primer 2019

Berdasarkan tabel tersebut menunjukan jawaban responden atas pertanyaan yang menyangkut Kesesuaian antara inpu,output dengan hasil pekerjaan yang tidak baik sebanyak 13 orang $(35,1 \%)$ dan Kesesuaian antara inpu,output dengan hasil pekerjaan yang baik sebanyak 24 orang $(64,9 \%)$

2) Pekerjaan sesuai dengan kemampuan

Tabel 9 Distrubusi Frekuensi Efektifitas Pelaksanaan Tugas berdasarkan Pekerjaan sesuai dengan kemampuan

\begin{tabular}{|c|c|c|}
\hline $\begin{array}{c}\text { Pekerjaan sesuai } \\
\text { dengan } \\
\text { kemampuan }\end{array}$ & \multicolumn{2}{|c|}{ Responden } \\
\cline { 2 - 3 }$(\%)$ \\
\hline Tidak Efektif & 15 & 40,54 \\
Baik Efektif & 22 & 59,46 \\
\hline Jumlah & 37 & 100 \\
\hline
\end{tabular}

Sumber : Data Primer 2019
Berdasrakan tabel tersebut menunjukan jawaban responden atas pertanyaan yang menyangkut Pekerjaan sesuai dengan kemampuan yang tidak baik sebanyak 15 orang $(40,54 \%)$ dan Pekerjaan sesuai dengan kemampuan yang baik sebanyak 22 orang $(59,46 \%)$

3) Tidak ada Perbedaan antar pegawai

Tabel 10 Distrubusi Frekuensi Efektifitas Pelaksanaan Tugas berdasarkan Tidak ada Perbedaan antar pegawai

\begin{tabular}{|c|c|c|}
\hline \multirow{2}{*}{$\begin{array}{c}\text { Tidak ada } \\
\text { Perbedaan } \\
\text { antar pegawai }\end{array}$} & \multicolumn{2}{|c|}{ Responden } \\
\cline { 2 - 3 } & $\mathrm{N}$ & $(\%)$ \\
\hline Tidak Efektif & 14 & 37,84 \\
Baik Efektif & 23 & 62,16 \\
\hline Jumlah & 37 & 100 \\
\hline
\end{tabular}

Sumber : Data Primer 2015

Berdasarkan tabel tersebut menunjukan jawaban responden atas pertanyaan yang menyangkut Tidak ada Perbedaan antar pegawai yang tidak baik sebanyak 14 orang $(37,84 \%)$ dan Tidak ada Perbedaan antar pegawai yang baik sebanyak 23 orang $(62,16 \%)$

4) Tidak ada Perbedaan antar pegawai Tabel 11 Distrubusi Frekuensi Efektifitas Pelaksanaan Tugas berdasarkan Tidak ada Perbedaan antar pegawai.

\begin{tabular}{|c|c|c|}
\hline \multirow{2}{*}{$\begin{array}{c}\text { Tidak ada } \\
\text { Perbedaan } \\
\text { antar pegawai }\end{array}$} & $\mathrm{N}$ & Responden \\
\cline { 2 - 3 } & $\mathrm{N} \%$ \\
\hline Tidak Efektif & 14 & 37,84 \\
Baik Efektif & 23 & 62,16 \\
\hline Jumlah & 37 & 100 \\
\hline
\end{tabular}


Tabel 12 Hubungan antara Variabel

Berdasrakan tabel tersebut menunjukan jawaban responden atas pertanyaan yang menyangkut Tidak ada Perbedaan antar pegawai yang tidak baik sebanyak 14 orang (37,84\%) dan Tidak ada Perbedaan antar pegawai yang baik sebanyak 23 orang $(62,16 \%)$

5) Penghargaan terhadap pegawai teladan Tabel 12 Distrubusi Frekuensi Efektifitas Pelaksanaan Tugas berdasarkan Penghargaan terhadap pegawai teladan

\begin{tabular}{|l|c|c|}
\hline \multirow{2}{*}{$\begin{array}{c}\text { Penghargaan } \\
\text { terhadap } \\
\text { pegawai teladan }\end{array}$} & $\mathrm{N}$ & Responden \\
\cline { 2 - 3 } & $\%)$ \\
\hline Tidak Efektif & 14 & 37,84 \\
Baik Efektif & 23 & 62,16 \\
\hline \multicolumn{1}{|c|}{ Jumlah } & 37 & 100 \\
\hline
\end{tabular}

Sumber : Data Primer 2015

Berdasrakan tabel tersebut menunjukan jawaban responden atas pertanyaan yang menyangkut Penghargaan terhadap pegawai teladan yang tidak baik sebanyak 14 orang $(37,84 \%)$ dan Penghargaan terhadap pegawai teladan yang baik sebanyak 23 orang $(62,16 \%)$.

\section{Analisis Bivariat}

Analisis bivariat betujuan untuk mengetahui hubungan antara variabel dengan variabel terikat dengan menggunakan uji Chi square $\left(X^{2}\right)$. Adanya hubungan Variabel Semangat Kerja Pegawai dengan Efektifitas Pelaksanaan Tugas ditunjukan dengan nilai $\mathrm{P}<0.05$. Pengujian secara statistik antara variabel Variabel Semangat Kerja Pegawai dengan Efektifitas Pelaksanaan Tugas ditampilkan pada tabel berikut:

Pelaksanaan Tugas

\begin{tabular}{|c|c|c|c|c|c|}
\hline \multirow{3}{*}{$\begin{array}{l}\text { Semang } \\
\text { at Kerja } \\
\text { Pegawai }\end{array}$} & \multicolumn{4}{|c|}{$\begin{array}{c}\text { Efektifitas Pelaksanaan } \\
\text { Tugas }\end{array}$} & \multirow{3}{*}{ P. } \\
\hline & \multicolumn{2}{|c|}{$\begin{array}{c}\text { Kurang } \\
\text { efektif }\end{array}$} & \multicolumn{2}{|c|}{ efektif } & \\
\hline & $\mathrm{N}$ & $\%$ & $\mathrm{~N}$ & $\%$ & \\
\hline Baik & 1 & 2,70 & 23 & 62,16 & \\
\hline kurang & 10 & 27,0 & 3 & 8,11 & 0.02 \\
\hline Baik & & 3 & & & \\
\hline \multirow{2}{*}{ Jumlah } & \multirow{2}{*}{13} & 29,7 & \multirow{2}{*}{24} & \multirow{2}{*}{81,27} & \\
\hline & & 3 & & & \\
\hline
\end{tabular}

Sumber : Data Primer 2019

Berdasarkan Tabel diatas diketahui bahwa responden yang memiliki semangat kerja yang baik terdapat 23 (62,16\%) responden yang mampu melaksanakan tugas dengan efektif dan 1 (2,70\%) responden tidak efektif dalam pelaksanaan tugas yang diberikan kepadanya.

Sedangkan responden yang memiliki semangat kerja kurang baik terdapat 3 $(8,11 \%)$ responden yang mampu melaksanakan tugas dengan efektif dan 10 $(27,03 \%)$ responden tidak efektif dalam pelaksanaan tugas yang diberikan kepadanya.

Hasil analisis statistik menunjukan nilai $\mathrm{P}=0.02<0.05$ berarti disimpulkan ada hubungan antara Semangat Kerja dengan Efektifitas Pelaksanaan Tugas pegawai di Kantor Sekretariat DPRD Kabupaten Buton Utara

Hasil penelitian ini memberikan makna bahwa semangat kerja merupakan salah satu faktor yang turut menentukan efektivitas pelaksanaan tugas yang diberikan. Pentingnya semangat kerja yang diberikan kepada pegawai dimaksudkan untuk menciptakan aparatur yang memiliki 
kemampuan, keterampilan, dan profesional dalam menjalankan tugas dan pekerjaan menjadi semakin penting. Keterkaitan antara semangat kerja dengan efektivitas pelaksanaan tugas dapat dikatakan bahwa bila semangat kerja yang diberikan kepada pegawai dilakukan secara rutin dan efektif, maka akan mendukung pelaksanaan tugas yang berkualitas.

Semangat kerja seseorang diindikasikan dari tingkat kedisiplinan mereka saat bekerja. Disiplin merupakan suatu sikap, tingkah laku dan perbuatan yang sesuai dengan peraturan dari perusahaan baik tertulis maupun tidak. Dengan adanya disiplin diharapkan sebagian besar peraturan dapat dijalani oleh pegawai dan pekerjaan dilakukan seefektif mungkin. Sebaliknya apabila kedisiplinan tersebut tidak dapat ditegakkan maka kemungkinan tujuan yang ditetapkan tidak dapat tercapai secara efektif dan efisien. Di Kantor Sekretariat Dewan Kabupaten Buton Utara sendiri kedisiplinan pegawi dapat dilihat dari kesiapan mereka dalam menjalankan dan melaksanakan perintah atasan, ketepatan waktu mereka dalam menjalankan tugas serta tingginya minat pegawai dalam menaati peraturan, tidak datang terlambat serta kesediaan mereka untuk selalu ramah bekerja dengan baik

Selain kedisiplinan kerja yang tinggi semangat kerja seseorang ditunjukkan pula oleh adanya hubungan yang harmonis antara rekan sekerja hal ini dapat dilihat dari seringnya mereka bekerjasama dalam menjalankan tugas-tugasnya. Kerjasama merupakan tindakan bersama-sama antara seseorang dengan orang lain, dimana setiap orang bekerja dengan menggerakkan tenaganya secara sukarela dan sadar untuk saling membantu guna mencapai tujuan bersama. Usaha kerjasama dari para pegaawai di samping dapat dilihat dari kesukarelaan dalam membantu pegawai lain yang memerlukan bantuan, juga dapat dilihat dari kekompakan pegawai dalam menyelesaikan pekerjaan yang memerlukan penanganan beberapa pegawai.

Indikator yang lain dari semangat kerja adalah antusiasme kerja atau kegairahan kerja yang tinggi. Kegairahan kerja adalah kesenangan yang mendalam terhadap pekerjaan yang dilakukan dan ketekunan dalam menjalankan tugastugasnya serta pantang menyerah dalam menghadapi kesulitan. Antusiasme pegawai Sekretariat Dewan Kabupaten Buton Utara tak jarang malah menimbulkan konflik.

Komponen terakhir yang menentukan baik tidaknya semangat kerja pegawai adalah loyalitas. Loyalitas tidak hanya berupa loyalitas antar pegawai, tapi juga loyalitas antara organisasi dengan pegawai dan loyalitas antar pegawai dengan organisasi. Loyalitas antar pegawai pada Sekretariat Dewan Kabupaten Buton Utara Sendiri berupa adanya rasa saling menghargai, saling bekerjasama serta adanya rasa solidaritas yang tinggi. Sedangkan loyalitas organisasi dengan pegawai dapat dilihat dari semua fasilitas yang diberikan organisasi kepada pegawai seperti adanya pelatihan-pelatihan untuk meningkatkan kemampuan pegawai

\section{Kesimpulan}

Berdasarkan hasil analisis dan pembahasan maka dapat ditarik kesimpulan bahwa Hasil analisis statistik menunjukan nilai sign. $0.02<0.05$ berarti disimpulkan ada hubungan antara Semangat Kerja dengan Efektifitas Pelaksanaan Tugas pegawai, sedangkan besar konstribusi semangat kerja sebesar 
62,16\% terhadap Efektifitas Pelaksanaan Tugas pegawai pada Kantor Sekretariat DPRD Kabupaten Buton Utara. Sedangkan, faktor yang mempengaruhi tinggi rendahnya semangat kerja antara lain Hubungan yang harmonis antara pimpinan dan bawahan, Kepuasan para pegawai terhadap tugas dan pekerjaannya, Terdapat suatu suasana dan iklim kerja yang bersahabat dengan anggota lain dalam organisasi

\section{Daftar Pustaka}

Idris, Adam, 2007. Kinerja Perusahaan Terhadap Kepuasan Palanggan, CV.Sofa Mandiri, Malang

Kusnadi, 2000, Pengantar Manejemen Strategi, Universitas Brawijaya, Malang Mahsun, Muhammad, Pengukuran Kinerja Sektor Publik, Yogyakaeta BD FE,

Mangkunegara Prabu Anwar, 2005. Evaluasi Kinerja SDM, Refika Aditama, Yogyakarta

Manullang,M, 2002, Dasar-dasar Manejemen, Gralia Indonesia, Jakarta.

Nasition, Mulia, 2003.Menejemen Personalia, Djambatan, Jakarta

Notoatmojo, Soekidjo, 2003. Pembangunan Sumber Daya Manusia, Edisi Revisi, Cetakan Kedua, PT Renika Cipta, Jakarta

Pasolong, Hanabi, 2007. Teori Adminitrasi Publik, CV. Alfabeta, Bandung

Sedarmayanti,2010. Manajemen Sumber Daya Manusia, Reflika Afitama, Bandung
Simamorang, Hendy, 2004. Manajemen Sumber Daya Manusia. STIE YKPN, Yogyakarta

Sugiono, 2003. Stastika Untuk Penelitian, CV. Alfabeta, Bandung. 